$\begin{array}{ll} & \text { Etnográfica } \\ \text { etnográfica } & \text { Revista do Centro em Rede de Investigação em }\end{array}$

Antropologia

vol. $22(2) \mid 2018$

Vol. $22(2)$

\title{
Arte como política de resistência: dispositivos cartográficos na apreensão de práticas culturais juvenis em uma cidade do Nordeste do Brasil
}

Art as politics of resistance: cartographic devices in the apprehension of youth cultural practices in the Northeast of Brazil

Denise H. P. Laranjeira, Mirela Figueiredo Iriart e Eduardo Luedy

\section{(Q) OpenEdition}

\section{Journals}

\section{Edição electrónica}

URL: https://journals.openedition.org/etnografica/5614

DOI: 10.4000/etnografica.5614

ISSN: 2182-2891

\section{Editora}

Centro em Rede de Investigação em Antropologia

\section{Edição impressa}

Data de publição: 1 junho 2018

Paginação: 427-452

ISSN: 0873-6561

\section{Refêrencia eletrónica}

Denise H. P. Laranjeira, Mirela Figueiredo Iriart e Eduardo Luedy, «Arte como política de resistência: dispositivos cartográficos na apreensão de práticas culturais juvenis em uma cidade do Nordeste do Brasil», Etnográfica [Online], vol. 22 (2) | 2018, posto online no dia 07 julho 2018, consultado o 19 janeiro 2022. URL: http://journals.openedition.org/etnografica/5614 ; DOI: https://doi.org/10.4000/ etnografica.5614

\section{(c) (7) \&}

Etnográfica is licensed under a Creative Commons Attribution-NonCommercial 4.0 International License. 


\section{Arte como política de resistência: dispositivos cartográficos na apreensão de práticas culturais juvenis em uma cidade do Nordeste do Brasil}

\section{Denise H. P. Laranjeira, Mirela Figueiredo Iriart e Eduardo Luedy}

$\mathrm{O}$ artigo pretende compreender o papel da arte nos processos de inserção social e política de jovens na cidade de Feira de Santana, Bahia, investigando a produção e difusão cultural de alguns coletivos e circuitos culturais juvenis, através de um estudo inspirado na etnografia urbana e na cartografia psicossocial. Estes circuitos são compreendidos como redes de sociabilidade, cujas dimensões formativas, estéticas, éticas e políticas são pouco conhecidas. Incluem grupos de músicos (hip-hop), dançarinos, artistas plásticos (grafiteiros), poetas, além de eventos que potencializam a sociabilidade entre jovens em suas diferenças culturais, étnicas, raciais e de gênero, criadas e gestadas à margem da cultura hegemônica. Aproximações empíricas com o campo implicam no olhar descentrado, captando o imprevisível, revelador de singularidades, em que sujeito e objeto são coemergentes. Os dispositivos metodológicos construídos foram observações participantes, acompanhando processos e percursos de jovens e coletivos culturais (ensaios, encontros); deambulações pela cidade, entrevistas realizadas à medida que caminhávamos por espaços afetivos escolhidos pelos jovens; registros fotográficos; grupos de diálogo e oficinas. Mais que delimitar territórios e suas formas de fruição, busca-se traçar as rotas ou redes onde os sujeitos se reinventam nas tensões e contradições do espaço urbano e como pensam sua relação com a cidade, seus desejos e projeções. Potencializar a construção de redes comunicativas, interativas e inventivas também são resultados esperados pela pesquisa-intervenção, contribuindo para uma perspectiva educadora (de si e do outro) que pode favorecer processos de pertencimento e cidadania.

PALAVRAS-CHAVE: culturas juvenis, territórios urbanos, método cartográfico.

Art as politics of resistance: cartographic devices in the apprehension of youth cultural practices in the Northeast of Brazil - This paper aims to understand the role of art in social and political integration of young people in the city of Feira de Santana, Bahia, Northeast of Brazil, investigating the production and cultural diffusion of some collectives and cultural circuits, through a study inspired by social cartography and urban ethnography. These circuits, connecting groups of musicians (hip-hop), K-pop dancers, visual artists (graffiti) and poets, are understood as social networks, whose formative, aesthetics, ethics and political dimensions are little known. Youth cultural circuits created and gestated on the margins of hegemonic culture can enhance sociability among young people in their cultural, ethnic, racial and gender differences. Empirical approaches 


\begin{abstract}
imply capturing the unpredictable singularities, in which subject and object emerge dialogically and dialectically. The methodological strategies developed were participant observation, accompanying practices and events among cultural groups and collectives; photographic records; interviews, walking through affective spaces chosen by the participants; dialogue groups and workshops. We intended to map and trace the routes and networks where subjective processes occurred, taking into account the tensions and contradictions in the urban space appropriation and cultural meaning-making among different cultural circuits drawn by the youngsters. More than to delimit territories of cultural practices, the study was concerned with promoting the construction of communicative and collaborative networks, where an educational perspective (of self and other) can mediate belonging and citizenship processes.
\end{abstract}

KEYWORDS: youth culture, urban territories, cartographic method.

LARANJEIRA, Denise H.P. (denise.laranjeira@gmail.com) - Departamento de Educação, Universidade Estadual de Feira de Santana (UEFS), Brasil.

IRIART, Mirela Figueiredo (mifis36@gmail.com) - Departamento de Educação, Universidade Estadual de Feira de Santana (UEFS), Brasil.

LUEDY, Eduardo (eluedy@gmail.com) - Departamento de Educação, Universidade Estadual de Feira de Santana (UEFS), Brasil.

\title{
INTRODUÇÃO
}

Tendo como base dados produzidos pela pesquisa "Circuitos de consumo e produção cultural entre jovens na cidade de Feira de Santana", no estado da Bahia, no Brasil, investigamos as expressões político-culturais juvenis e suas implicações estéticas, éticas e formativas por meio de observações participantes e de outras estratégias complementares, explicitadas mais adiante.

Imergimos no espaço urbano e nas suas bordas, como espaço de produção de arte, cultura e política. Seguindo Magnani (2005), propusemo-nos estudar os agrupamentos juvenis contemporâneos, empregando a noção de "circuitos jovens", buscando articular as referências comportamentais dos sujeitos no uso e na apropriação do espaço. Nestes circuitos, a arte apresenta-se como um elemento fundamental de produção e agregação de sentidos, além de demarcar identidades e fronteiras simbólicas.

O estudo sobre as culturas juvenis a partir da noção de circuitos de consumo, produção e difusão cultural leva em consideração elementos sociais, espaciais e intersubjetivos na tentativa de compreender as dinâmicas de apropriação, ressignificação e resistência cultural juvenil contemporâneas. Essas formas de agrupamento juvenil, fluidas e em movimento, potencializam o capital social e comunicativo dos jovens na relação intergrupal e geracional, sobretudo se 
levarmos em consideração a carência de espaços públicos que visibilizem a ação juvenil.

Conhecer os circuitos culturais juvenis na cidade Feira de Santana, Nordeste do Brasil, implicou mais do que delimitar territórios, significou descobrir produções surpreendentes, a exemplo de grandes festivais de rock e de pop oriental, e reconhecer as ações juvenis, espontâneas ou organizadas, em suas linguagens múltiplas, circunscrevendo espaços físicos e simbólicos por meio da poesia, do grafite, do hip-hop, do pop coreano (K-pop), do cosplay. Os jovens, com suas práticas culturais, por vezes inusitadas e tendo por influência culturas globalizadas transnacionais, parecem buscar preencher vazios culturais, num espaço urbano tenuamente industrial e tradicionalmente comercial e com pouco investimento em urbanização e arte pública, sobretudo nas áreas periféricas.

O que nos motivou nesta direção foi a possibilidade de produzirmos conhecimentos que pudessem contribuir para uma maior visibilidade das culturas juvenis, por meio de observação participante, entrevistas em profundidade, grupos de diálogo e oficinas, ações pensadas como dispositivos importantes para imergir nas práticas culturais juvenis, em seus contextos e em sua diversidade.

Buscaremos um diálogo entre os dados empíricos e os argumentos teóricos de onde partimos para entender as práticas culturais como centrais na análise das posições sociais ocupadas pelos jovens, considerando suas diferenças sociais, étnico-raciais e de gênero, e como dispositivos de reinvenção de si e de reivindicação social (García Canclini 1997; García Canclini, Cruces e Urteaga 2012; Hall 2004; Hall e Jefferson 2006; Duncombe 2002). O texto apresentará uma caracterização de grupos culturais, revelando percursos biográficos de lideranças jovens que agregam o papel de artistas e de mobilizadores culturais, ao tempo em que são trabalhadores, estudantes, pais e filhos.

Ao descrevermos as práticas culturais e seus imbricamentos com trajetórias biográficas de lideranças juvenis, buscaremos entender a importância da arte como recurso criativo e simbólico ao produzir mudanças na (re)apropriação do espaço e na produção de subjetividades. Por fim, intentaremos mostrar a produção criativa de dispositivos teórico-metodológicos que, a nosso ver, potencializam a apreensão do fluxo de acontecimentos e afetos no campo da pesquisa e o compromisso político e ético da pesquisa-intervenção, tal como proposto pelo método cartográfico.

\section{CIRCUITOS CULTURAIS JUVENIS}

O estudo sobre as culturas juvenis demarca um campo tensionado por questões geracionais e de classe, por um lado, acompanhando uma tradição estruturalista, e, por outro, numa vertente pós-estruturalista, realça elementos processuais, biográficos e de estilos na caracterização das práticas culturais juvenis, 
seja como resistência cultural, ou na busca por autonomia e agenciamento (Bennet 201 1; Bennet e Robards 2012; Johansson e Lalander 2012; Dedman $2011)$.

Desde meados da década de 1990, novas categorias de análise vêm sendo colocadas em discussão, como as noções de neotribalismo, cenas, clubes e estilos de vida, que levam em consideração a natureza fluida e porosa das fronteiras sociais, a dinâmica interativa e a hibridização na negociação dos símbolos culturais, sem essencializar ou fixar as identidades coletivas ou individuais.

Clarke et al. (2006) discutem a heterogeneidade e as diferentes combinações na apropriação da cultura e desmontam a ideia de identificações fixas e demarcadas em contextos sociais específicos - seja por posições de classe ou diferenças geográficas -, reconfigurando a relação entre local e global, periférico e hegemônico, consumo e produção. Segundo os autores, a cultura é uma prática que realiza e objetiva os estilos e significados produzidos coletivamente, oferecendo um mapa de significação no compartilhamento, compreensão e interpretação de experiências singulares, que podem ser reproduzidas e/ou (re)significadas num campo de possibilidades e limites. O que importa é o que se pode realizar a partir e através da cultura, já que ela não é apenas consumida: no ato mesmo de consumir bens culturais, está-se criando e produzindo algo novo.

Podemos pensar, por exemplo, que apesar das limitações sociais e políticas que não permitem que uma ruptura radical com a ordem seja levada a cabo, há um empoderamento cultural que parece ampliar o capital social de jovens em territórios marginalizados. Através de expressões como o hip-hop, o grafite e a poesia, relações de poder podem vir a ser desestabilizadas, alargando possibilidades de ação e participação social. Neste sentido, a mediação criativa via arte e imaginação é um dispositivo importante na construção ativa de respostas individuais e coletivas, numa tentativa de superação de situações de exclusão e de privação, como sugerem Jovchelovitch e Priego-Hernandez (2013), quando novos atores podem fazer emergir formas de resistência e de regeneração das comunidades periféricas.

Assim, García Canclini (1997) chama atenção para as novas cartografias sociais que reorganizam forças em constante tensão e contradição na dinâmica social. E ainda que não negue as diferenças nas formas de apropriação e produção dos bens materiais e simbólicos em sociedades desiguais, o autor observa que as culturas de fronteira dão a tônica nas formas de intercâmbio, tanto na fusão de gêneros (música, poesia, grafite, por exemplo), quebrando fronteiras geográficas antes rígidas, quanto na apropriação sincrética que cada espectador/consumidor realiza a partir dos seus gostos. A obliquidade dos circuitos simbólicos, segundo o autor, permite repensar as relações entre cultura e poder.

A partir das reflexões e considerações teóricas até aqui esboçadas, passamos a seguir para a descrição da investigação propriamente dita, circunscrevendo 
atores, situações e acontecimentos. Apresentaremos, portanto, um dos circuitos observados (hip-hop) e dois grupos culturais (um literário e outro de dança K-pop), mapeados através da imersão no campo da pesquisa, em uma tentativa de descrever as práticas e territórios ocupados pelos jovens, configurando cenários distintos, e conectados pelas redes de sociabilidade, sejam elas virtuais ou presenciais.

\section{ANCORAGENS E VOOS: DESCREVENDO AS ETAPAS DA INVESTIGAÇÃO}

Desde uma abordagem etnográfica, agregamos a potencialidade inventiva da cartografia psicossocial para acessar um campo de pesquisa aberto à experimentação e ao encontro com seus participantes. Consideramos relevante o posicionamento da equipe de pesquisa em campo, nas nossas diferenças culturais, geracionais e de gênero, como elementos significativos no processo da investigação-ação, assim como os processos intersubjetivos emergentes na relação dialética entre pesquisador e pesquisado, sujeito e objeto, real e imaginário.

A cartografia propõe dispositivos metodológicos tendo por base os princípios do construtivismo piagetiano, a noção de coengendramento de Maturana e Varela e os estudos de produção de subjetividade de Deleuze e Guattari, como apresenta Kastrup (2010). Elencamos alguns dispositivos que nos foram inspiradores: (a) a implicação do pesquisador no território pesquisado; (b) a preocupação com os processos intersubjetivos, em um duplo movimento que desestabiliza sujeito e objeto e que produz a emergência de novas subjetividades; (c) o entendimento do campo social como um campo de desejos e de forças; (d) a compreensão de que o plano da investigação é aberto e que novos arranjos são produzidos no percurso investigativo, uma vez que suas fontes são múltiplas e podem se originar na escuta, na escrita, na imagem, no movimento, na busca das expressões e intensidades que não se reduzem à representação.

Se cartografar é acompanhar processos, a imersão no campo da pesquisa tem mais do que a função de interpretá-lo. Compreender o espaço urbano através dos circuitos juvenis é uma possibilidade de exercitar o olhar descentrado do cartógrafo, levando em consideração os múltiplos centros e forças em que se engendram os sujeitos nas suas redes de sociabilidades, comportamentos e estilos de vida.

No período de julho de 2013 a julho de 2014, por meio de anotações de campo, entrevistas, observações participantes e ensaios fotográficos, fomos nos aproximando dos grupos culturais, seus cenários e atores, debatendo e perscrutando o papel articulador e mobilizador de suas ações, ao produzirem arte nas margens - sejam geográficas, sociais ou simbólicas. Assim, buscamos uma observação ativa de suas práticas e um entendimento dos valores e significações produzidos pelos sujeitos, deixando-nos afetar pela imprevisibilidade e abertura da dinâmica interativa no campo. Nessa incursão etnográfica, de câmera na 
mão pelas ruas na cidade, fomos reconhecendo os trajetos percorridos pelos(as) jovens, incluindo os "espaços evitados" e estigmatizados (Rocha e Eckert 2003).

Num primeiro momento, buscamos por entre $b \operatorname{logs}$, redes sociais, canais do YouTube, encontrar alguns dos agrupamentos e coletivos culturais juvenis da cidade. Para nossa surpresa, grupos diversos envolvidos com música, dança, grafite e poesia figuravam no ciberespaço. A partir daí, identificamos parte de suas produções artísticas e buscamos classificá-los em termos das atividades que desenvolviam. Além disso, nos chamava a atenção a existência de certos circuitos culturais, através dos quais diversos destes grupos articulavam-se em torno de eventos organizados e promovidos por eles próprios.

Após a descoberta e a coleta das informações iniciais sobre os atores individuais e seus coletivos, relativamente às suas práticas e territórios, partimos para a realização de encontros com alguns dos jovens contatados. A nossa entrada neste cenário foi facilitada pela mediação de uma jovem pesquisadora do nosso grupo que nos ajudou, através de sua rede de relações, a travar nossos primeiros contatos pessoais com alguns destes coletivos. Passamos a promover rodas de conversa com grupos e atores diversos e aos poucos fomos, assim, ampliando a rede de participantes.

As rodas de conversa aconteceram num centro cultural da cidade que parte dos grupos já costumava frequentar. Em nossos encontros, buscamos tematizar questões sobre as práticas culturais e a identidade social dos grupos e questões ligadas à política cultural do município e ao papel da universidade face às suas demandas sociais - a partir dos dois primeiros encontros, discutimos, por exemplo, a organização de uma mostra cultural e a realização de oficinas de vídeo-arte, utilizando o potencial criativo dos grupos e o intercâmbio com outros profissionais. Buscávamos sobretudo, compreender a relação dos jovens com a cidade.

Posteriormente, entrevistas narrativas foram realizadas individualmente com jovens selecionados pela emergência e relevância do seu papel mobilizador e articulador, em locais e contextos cotidianos escolhidos pelos participantes (numa praça, na escola, na casa dos pais, num centro cultural), aproximando-nos dos seus universos sociais.

Recortamos alguns elementos que nos ajudaram a compreender como os coletivos culturais funcionavam enquanto lugar de sociabilidades e pertencimento, onde identidades são produzidas, linguagens são desenvolvidas e processos criativos são alavancados, afetando a vida dos sujeitos e da comunidade, assim como amplificando o diálogo com a esfera pública.

Observamos um circuito vinculado ao movimento hip-hop da cidade, no qual jovens de periferia, mesclando música, dança e grafite, buscam um empoderamento a partir de suas comunidades de origem. Conhecemos artistas independentes que opõem-se, deliberadamente, à cultura hegemônica dos meios massivos, buscando novas sensibilidades estéticas através da poesia, 
da literatura e da realização de eventos multiartísticos. Pudemos perceber também grupos culturais ligados à cultura de mídia, desenhando um circuito híbrido de geeks, gamers e cosplayers, através dos quais estes jovens recriam localmente referências transnacionais oriundas das mídias audiovisuais e digitais na produção, consumo e disseminação cultural.

Por meio da fala de algumas destas jovens lideranças, vamos descrever os percursos e rotas que se aproximam, constituindo redes e circuitos, ou outras vezes revelando o isolamento e a marginalização como efeitos das diferentes formas de ocupação e reinvenção das fronteiras da cidade.

\section{ARTE NA RUA: "ELA TEM ESSE PODER DE CHAMAR - VENHA! ACORDE!"}

Através de registros em áudio, fotográficos e das nossas impressões, fomos afetados pelo lugar, pelos seus contrastes e intensidades, como os grafites desenhados nas paredes cinzas e em meio a ausência de equipamentos de lazer e urbanização que caracterizam alguns dos bairros que conhecemos. O que recortamos desta árida paisagem urbana foi a presença de uma autoria criativa, individual ou coletiva, da arte que vem das margens, seja em forma de poesia, da música ou do grafite.

Denominamos micropolítica das margens a capacidade de resistência e existência criativa (potência do agir) em que grupos, coletivos e indivíduos, ao longo das suas trajetórias, apropriam-se significativamente da cultura. Levamos em consideração o ponto de vista de Johansson e Lalander (2012) sobre resistência, como estratégias temporárias, parciais e processuais construídas na interação ambígua entre diferentes escalas de poder, na relação entre as estruturas sociais e os processos de significação cultural.

Concordamos com Das e Poole (2009: 19) quando afirmam que "as margens não são simplesmente espaços periféricos", entendidos enquanto zonas de perigo ou onde há submissão aos estigmas. Nas palavras das autoras, paradoxalmente esses espaços também visibilizam "a criatividade das margens" e ações com sentido político, porém nos limites de uma realidade crítica no cotidiano de suas populações.

\section{Kbça Grafite}

Geziel Ramos, ou Kbça Grafite, tem 25 anos no momento da pesquisa, mora no conjunto habitacional Fraternidade, um dos mais populosos da cidade, que, assim como tantos outros bairros de periferia, caracterizados pela segregação socioespacial, sofre com a precarização dos equipamentos públicos de esporte/lazer e as dificuldades com saneamento e transporte coletivo ineficientes. Concluiu o ensino médio em 2010, trabalha informalmente como educador social num centro de atendimento a jovens em conflito com a lei e pretende tentar o ensino superior em artes visuais. Encontramo-nos para realizar a entrevista 
numa praça central do bairro em frente a um antigo mercado abandonado, onde realizou o seu primeiro grafite junto ao coletivo NdF (Nós de Feira).

Kbça aprendeu a grafitar na adolescência, quando conciliou seu talento no desenho com a oportunidade que encontrou para desenvolver habilidades com as latinhas de spray nos muros da cidade. Participa do coletivo, o que considera ser a sua motivação enquanto artista de rua, "o grupo se completa, em termos de arte, completa também o pessoal, o NdF todo, reunido, pintando, aquilo ali cria uma identidade pra todo mundo".

A forma como o artista intervém e se apropria dos espaços públicos da cidade se dá através do grafite. Sem precisar de galerias ou museus, sente-se livre para explorar as superfícies brancas dos muros da cidade, seja do centro ou da periferia, nas quais imprime seu traço e suas cores, já reconhecidos por vários moradores de seu bairro e adjacências.

"Feira de Santana não é uma cidade que tá acostumada a consumir um lance cultural mesmo, de identidade, que é frequentar museus, por exemplo, eu fico injuriado porque o museu daqui é fechado [no] final de semana [...] Então, como é que uma população vai conhecer o trabalho de um artista?

Acho que o lance de ta' pintando sempre nas ruas já vem da história do... É essa reivindicação mesmo. Antigamente, a galera que fazia grafite era totalmente excluída dos museus, eles não conseguiam expor em galerias, porque a galera não reconhecia o grafite como arte, então o que foi que a galera começou a fazer? Utilizar mesmo dos espaços pra mostrar".

O contato com jovens nos bairros periféricos onde realiza suas intervenções tornou-se um grande estímulo para continuar em sua trajetória de grafiteiro e também como arte-educador. Ele diz enxergar um papel social forte em seu trabalho, já que abordam temas referentes à cidade e à liberdade.

Como morador da periferia, ele conhece muito bem a realidade dos jovens que vivem assediados pelo tráfico e tenta mostrar que, com a arte, outros campos de possibilidades engendram-se, oferecendo novas ancoragens para os sujeitos (re)significarem seus trajetos e potencializarem sua identidade social. A arte surge, então, como um escape para que o jovem veja que através dela há possibilidades de crescer e ir além:

"Eu moro em bairro periférico, eu sei qual é a realidade. Na verdade, a gente não pode fugir disso, que quem são os salvadores da pátria são os traficantes que tão lá, ostentando e ganhando dinheiro no fácil. Então, eu procuro mostrar pra eles [outros jovens do bairro] que tem outras soluções, que tem outras saídas. Que o fato de ele ser um morador periférico não faz ele menor, que ele pode ser o que ele quer e correr atrás da onda dele". 
Kbça reflete sobre a importância da arte na potencialidade de encontro com o outro e de multiplicação de um discurso emancipatório e contestatório. Podemos entender a sua arte enquanto recurso simbólico de resistência cultural, na mediação da transformação social, por meio da propagação de novas ideias, como sinalizado por Duncombe (2002).

“[...] É passar uma mensagem pra essa gurizada [criançada] que tá passando ali e fala 'porra velho [espera aí, camarada!], os caras poderiam ta' enchendo a cara aí [se embriagando], poderiam ta' fazendo a porra toda [fazendo algo ilícito], mas os caras tão ali, pintando, sem ganhar nada’. É o guri que para e fala 'porra, eu gosto de desenhar, como é que eu faço isso?' Então, eu acho que o lance é a multiplicação”.

O espaço da praça é árido, o mercado abandonado mancha de cores a paisagem envelhecida. Nos seus muros estão um dos primeiros grafites do artista e outros do seu grupo. Aproveitamos para fazer alguns registros fotográficos e caminhar pelo bairro, conversando com Kbça sobre a sua percepção do lugar, sua motivação para pintar e sua relação com a cidade.

No momento da entrevista, Kbça encontra-se com uma velha conhecida, jovem trabalhadora em uma das barracas de comida local, que emociona-se ao perceber pela primeira vez a beleza do grafite nos muros do antigo mercado, descobrindo algo que sempre esteve ali, mas que agora a afeta e produz uma nova visibilidade: "A ideia de ta' na rua é isso aí, como a gente tava

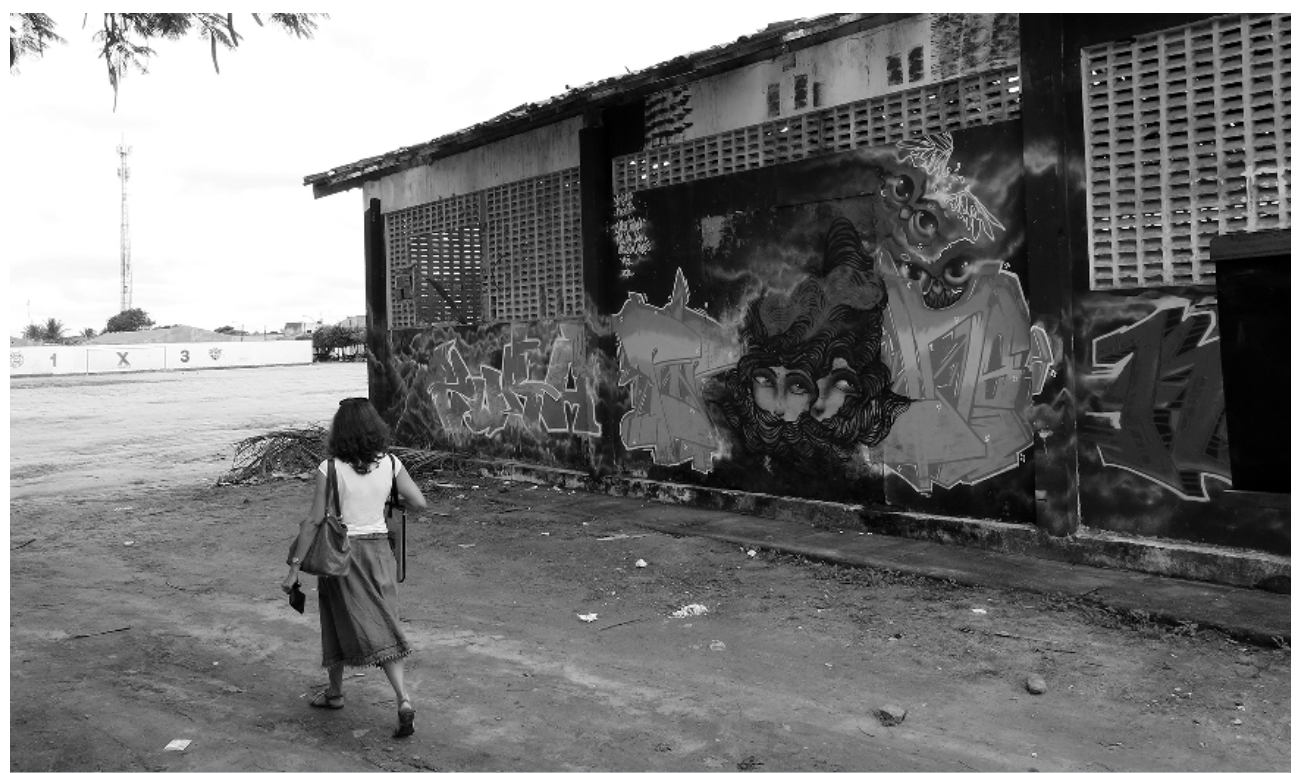

Figura 1 - Grafites no mercado abandonado. 


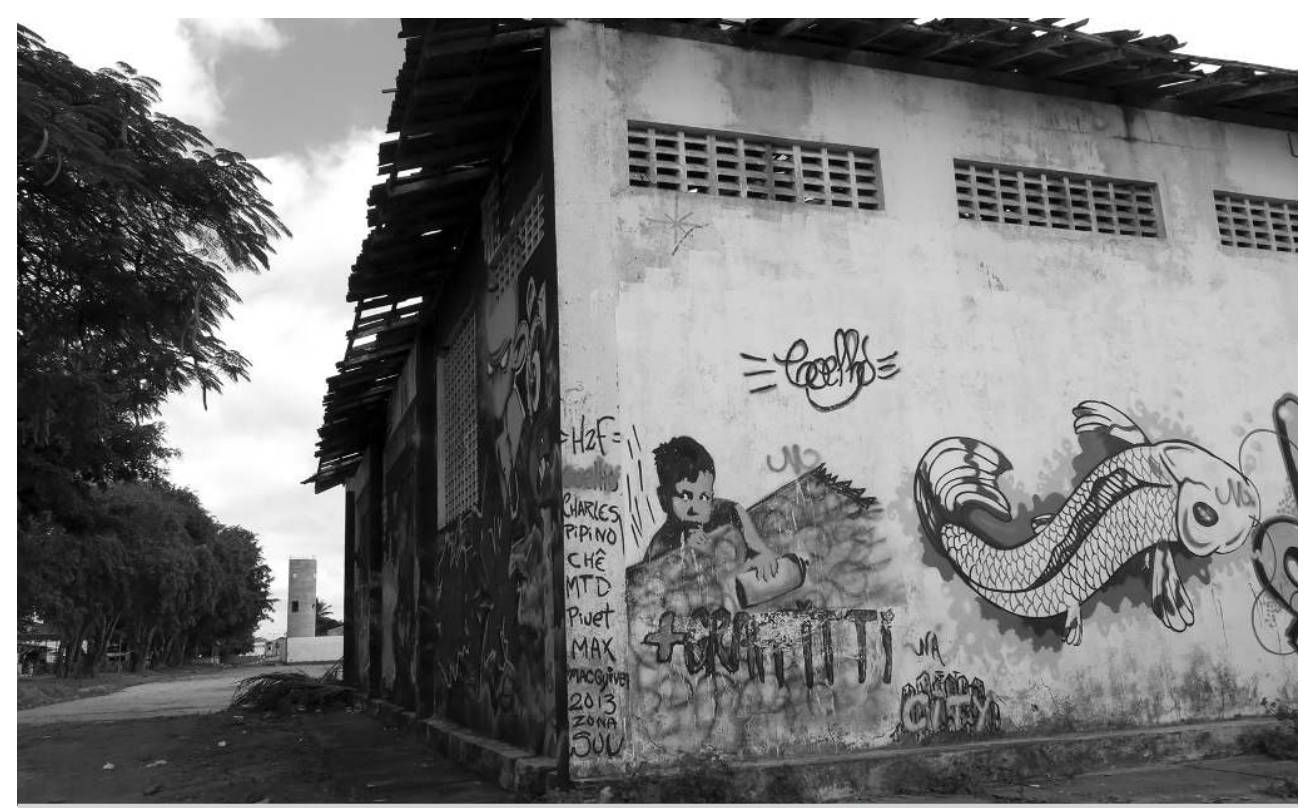

Figura 2 - De outro ângulo: grafitagem nos muros do mercado abandonado.

conversando, que a gente pode fazer, pode transformar, que é o papel do grafite, é a transformação. Não só a transformação estética, como a transformação social".

Kbça tem mostrado, por meio dos seus traços, que os jovens podem exercer seus protagonismos, transformando espaços de exclusão em locais de emergência de processos criativos. Esta possibilidade de transformação social e estética nos permite refletir acerca do alcance da intervenção artística que, nesse caso, não deixa de operar uma "sensação de cidadania" (Arantes 2000: 47, apud Tommasi 2013: 20), ou seja, um sentido amplo de cidadania das diferenças enquanto multiplicidade étnica, artística, geográfica, como trazido por Pais (2005) e Miller (201 1), na apropriação cultural significativa do espaço urbano, o que repercutiria não apenas no capital simbólico, como igualmente no capital social.

\section{Ivan Coelho}

Ivan Coelho, com 22 anos no período da pesquisa, mora no conjunto habitacional Feira VII, bairro de periferia, território limítrofe ao conjunto Fraternidade e que com ele guarda muitas semelhanças em termos de suas dificuldades. Após três anos afastado da escola, retornou aos estudos e cursa o primeiro ano do ensino médio noturno, aliando o trabalho como auxiliar de almoxarifado em uma fábrica de produtos químicos. No momento da entrevista nos encontramos no pátio externo da escola onde estuda para a terceira jornada do seu dia. 
Em seu bairro, Ivan realiza com o coletivo Vozes algumas intervenções culturais, como a exibição de filmes e documentários, seguidos de discussões e outras ações de integração cultural com o hip-hop e o grafite. As intervenções realizadas pelo grupo pretendem atingir a comunidade onde mora, possibilitando espaços de reflexão e de lazer, que são, segundo ele, uma das carências do local.

Acredita, assim como outros artistas da sua geração, na possibilidade de proliferação e (re)ocupação do espaço urbano via arte, como resgate e alternativa à criminalidade, além de acreditar na sua dimensão de formação e desenvolvimento pessoal, começando com a sua própria experiência de vida: "Ela [a arte] tem um papel de resgate, um papel social, um papel didático. E eu acho que a falta de ocupação é o que leva realmente à criminalidade, a falta de opção".

Sobre sua relação com a arte, Ivan diz: "ela me norteou, me deu uma referência”. Em suas obras, a intenção é a de deixar uma mensagem na rua, para que as pessoas possam ser confrontadas com aquilo e reflitam sobre a mensagem transmitida pelo grafite.

O jovem vê na arte um elemento de transformação e demonstra interesse em trabalhar, além da própria produção artística, num processo de formação de outros jovens, mostrando outros caminhos e possibilidades: "E você vê que a arte, ela tem esse poder de chamar - 'Venha! Acorde!' Entendeu? É por isso que a gente tem essa preocupação de estar formando através da arte, porque ela tem esse poder e é forte".

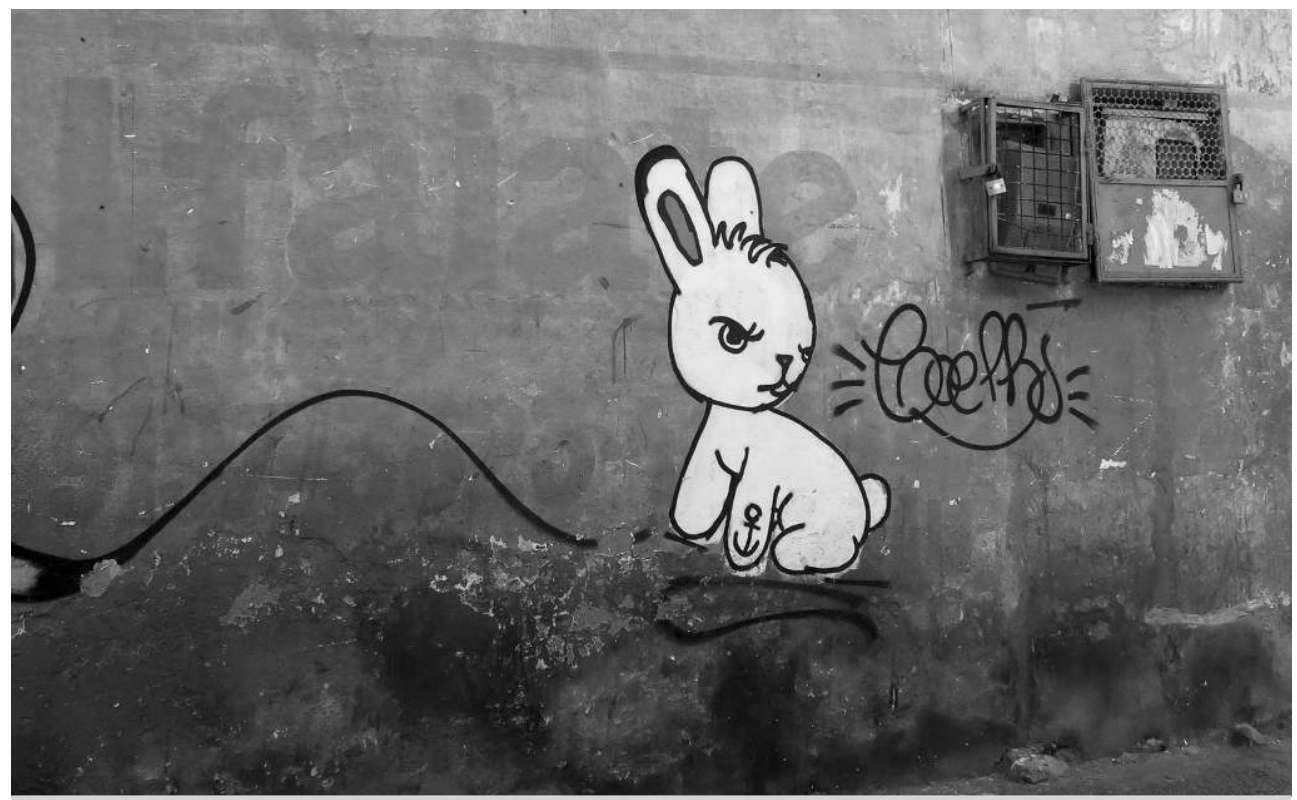

Figura 3 - Num muro, no centro da cidade: a arte de Coelho. 
Como linguagem, o grafite transfigura a palavra em imagem e constitui-se em ato. Como processo criativo, Ivan revela que expressa o que pensa e sente por meio do desenho, primeiro no papel, depois para a parede, já que diz não ser bom com a escrita. Na sua trajetória pessoal, o desenho vem ocupando um espaço existencial que o ajudou na adolescência a lidar com os limites sociais e geográficos da vida na periferia, circunscrevendo novas possibilidades de ação e interação social.

Através do grafite, seguindo Campos (2009) que o toma como escrita, ou marca de autoria, muitas vezes transmutada em anonimato, os writers (sob pseudônimos criados pelos próprios grafiteiros) tornam-se agentes intervindo na arquitetura da cidade, criando outros planos sobrepostos. A marca do novo nome que identifica o artista nos muros cria um reconhecimento público com forte significado simbólico, ressignificando as identidades individuais e situando-as num contexto histórico e social. A rua é então reivindicada como espaço de criatividade e emancipação: "Eu quero financiar minha arte, aumentando a formação do público e também com esse despertar social, sempre provocando alguma reflexão, para provocar um despertar, entendeu? Tento fazer isso, levando sempre a mensagem".

\section{Léo $E Z$}

Nascido e criado no conjunto Fraternidade, Leandro Lima ou Léo EZ, 27 anos, é um dos principais criadores do grupo de rap Efeito Zumbi (existente desde 2000), que tem um papel de contestação, reflexão e intervenção social. O jovem concluiu o ensino médio e trabalha como agente de portaria (vigilante) e como educador social, em oficinas de hip-hop para jovens em conflito

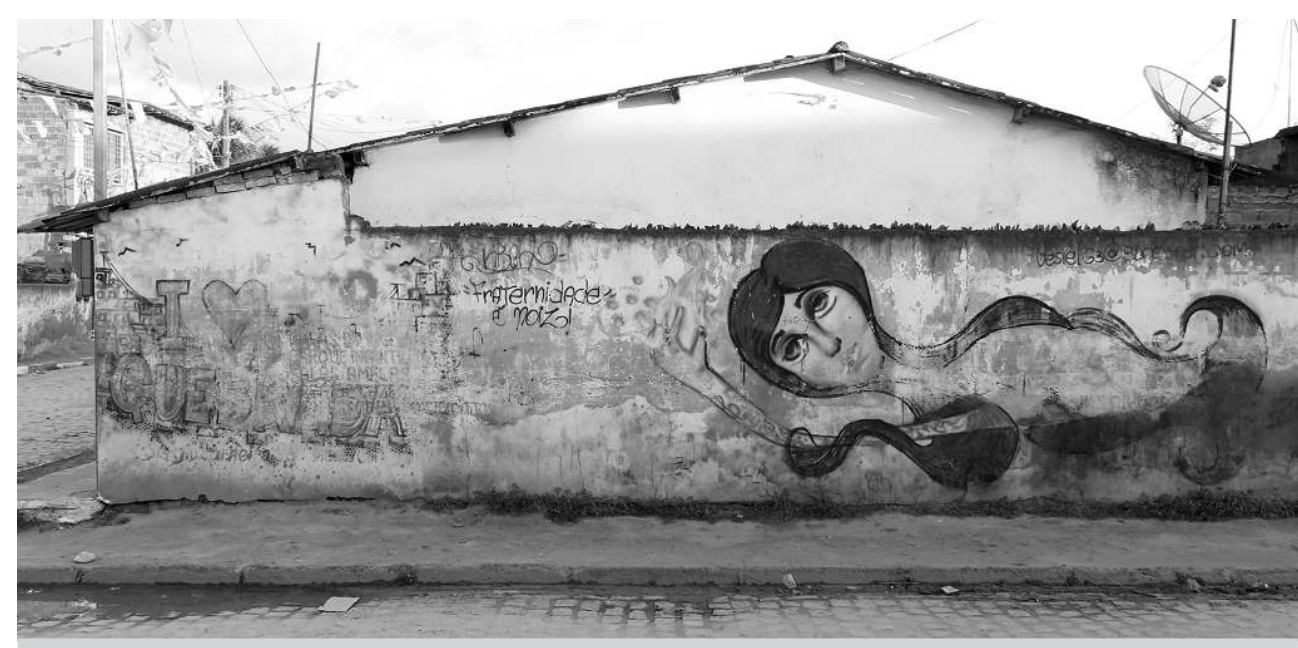

Figura 4 - Grafite no muro do conjunto Fraternidade. 
com a lei. Fomos de táxi até o bairro, cujo acesso é difícil via transporte público, fato comum nas áreas mais pobres da cidade. Nas palavras do condutor íamos a um "lugar barra pesada", uma impressão própria dos estigmas alimentados pela mídia. Nosso entrevistado vem ao nosso encontro de moto, veículo fortemente empregado por jovens e trabalhadores. Encontramo-nos para a entrevista na casa dos seus pais, no bairro onde nasceu e de onde emergiu a sua arte. Chamou-nos a atenção o fato de as ruas do bairro serem nominadas a partir da Bíblia. É na rua Salmos, 33, que mora a família evangélica de Léo. Na ocasião da entrevista, véspera da Copa e dos festejos juninos, as ruas se encontravam enfeitadas com bandeirolas, algo típico de bairros populares onde há maior interação entre vizinhos.

Com uma participação política consolidada no cenário hip-hop de Feira de Santana, o Efeito Zumbi tenta desenvolver projetos nas áreas culturais e sociais em diferentes pontos da cidade, incluindo os bairros periféricos, marcados pela ausência de equipamentos culturais e esportivos, além de estigmatizados pela mídia. Segundo Léo, existe uma "cultura produtiva na periferia”, existem talentos desconhecidos, como também o desejo de lutar por um país melhor.

Para Léo, o rap constitui um instrumento de denúncia, com forte cunho político. Em suas letras, como na maioria dos grupos de rap do país, estão presentes a realidade de quem mora na região suburbana da cidade e a consciência de uma condição social desigual. Tratam das desigualdades sociais dos moradores da periferia, da discriminação racial e da violência sofrida sobretudo pelos jovens negros.

Léo é um reconhecido MC e presidente da Associação H2F. Assim, sua inserção afetiva, política e artística no bairro e na cidade tem um sentido de emancipação e de mudança, nas condições precárias e de risco a que são submetidos crianças e jovens.

O contato com o hip-hop, pela primeira vez, foi quando escutou o CD "Sobrevivendo no inferno”, dos Racionais Mc's, trazido por um amigo vindo de São Paulo. Sentiu, ao escutar o CD, grande identificação com a situação de vida dura, difícil, retratada nas letras dos Racionais Mc's.

"Descobri que a música tinha a ver comigo - as letras, tratando dos homicídios, assassinatos de jovens negros, a polícia, as drogas, enfim a violência, que também atingia os jovens dos bairros. A realidade que eles cantam na música é muito parecida com nossa realidade aqui também. Com aquela coisa da bandidagem, do tráfico de drogas, das coisas erradas, dos homicídios e coisa também da população negra".

A música em seus diferentes estilos (rap, rock, punk, etc.) vem se constituindo como espaço aglutinador, onde os jovens realizam, com suas performances, novas apropriações e significações da cultura e do espaço urbano, 
realinhando as relações centro e periferia, local e global, em um exercício de autonomia criativa, ampliando a capacidade de agenciamento juvenil, sobretudo quando acessam meios e recursos de produção artística e de comunicação (García Canclini, Cruces e Urteaga 2012).

Menos do que apropriações homogeneizadoras, pela mera incorporação das culturas globais, movimentos periféricos, como o hip-hop, podem indicar processos de criação e inovação, produzidos pelos jovens como agentes culturais, dinamizando a cultura (Cho 2010).

"[...] pra mim, $[\ldots]$ o reconhecimento tem que ser dentro de onde você está. [...] de onde você saiu mesmo, pra que hoje vocês estivessem aqui, eu tive toda uma história primeiramente aqui. Esse lugar aqui, que praticamente é a base de tudo, a base familiar [...] Então, assim, minha ideologia principal é de que existe uma cultura produtiva na periferia, existem pessoas que têm vários outros talentos nas periferias, a gente vê isso infelizmente, definhando e morrendo dia a dia".

O compartilhamento de experiências e as redes de amizade são aspectos vitais na construção do movimento hip-hop na cidade, algo que mescla arte, discurso político e intervenção comunitária. Os aspectos contestatórios e de denúncia social caracterizam as práticas artístico-culturais destes grupos, potencializando um importante instrumento de reivindicações juntos às esferas públicas, oportunizando uma participação criativa e, mais que tudo, uma dimensão formativa na compreensão de si e do outro.

Em nossas conversas com Léo, identificamos aquilo que Raposo (2012: 335) diz acerca de a cultura hip-hop ser um disparador de ações e de encontros, que fomenta o fluxo dos jovens para além das fronteiras da periferia, possibilitando a sua circulação para outros territórios da cidade e potencializando a ação destes sujeitos, ao propor novos usos da cidade através de ações mobilizadoras, exercendo uma "cidadania insurgente".

Vale observar que a escassez de espaços culturais públicos nos bairros onde moram leva os jovens do circuito do hip-hop a utilizarem lugares não convencionais para a realização de eventos: um bar e mercearia no bairro Fraternidade, por exemplo, abre suas portas para grafiteiros, DJs, MCs, rappers que se juntam aos frequentadores diversos do bairro: dos sóbrios aos bêbados. Os eventos ocorrem na calçada de ruas com esgoto a céu aberto. Esse "pedaço", espaço entre a casa e a rua, como nos ensina Magnani (2005), configura um espaço de sociabilidade que acaba por constituir um ambiente de compartilhamento de experiências por meio da arte peculiar a cada indivíduo ou grupo. E assim vimos os muros das casas, do pequeno comércio e terrenos baldios tomados pelo colorido do grafite. Ao mesmo tempo, os MCs e rappers e DJs, em sua maioria negros, se revezavam no "palco", entoando letras reveladoras 
de uma recusa à resignação ao denunciarem a violência policial, as drogas, a corrupção no país, etc. Na ocasião, observamos mulheres espreitando o movimento da rua atrás dos portões gradeados de suas casas. A rua não é, para todos, sinal de segurança e proteção.

Outro espaço, a chamada "Praça da Alimentação", no centro da cidade de Feira de Santana, poderia constituir a "mancha" (Magnani 2005: 178), enquanto área dotada de equipamentos que facilitam os encontros. Um lugar com muitos bares, restaurantes, casas comerciais e de grande circulação de carros, ônibus e gentes, mas sobretudo de jovens. Aqui também é onde os $B$-boys, street dancers, skatistas, poetas, grafiteiros, MCs, expõem seus símbolos, seus valores, suas linguagens visuais, corporais, enfim, seus códigos de sociabilidades e pertencimento, preenchendo criativamente a cidade.

O beco da Energia, igualmente localizado no centro, é um espaço de ocupação recente, agregando eventos, especialmente do circuito hip-hop, ressignificando o imaginário estigmatizado, associado à prostituição, drogas e criminalidade, etc., sobre esse lugar "maldito". As intervenções artísticas na forma de música, dança e grafite vêm o transformando nos fins de semana em espaço cultural alternativo, sem perder, no entanto, suas características de marginalização. Os artistas dividem espaço com as antigas prostitutas, negociando suas formas de estar, ocupar e reinventar espaços subterrâneos, estetizando a cidade. Como notam Rocha e Eckert (2003: 102): "A cidade é estrutura e relações sociais, economia e mercado; é política, estética e poesia. [...] é igualmente tensão, anonimato, indiferença, desprezo, agonia, crise e violência”.

Outros espaços formais, institucionalizados e não sistemáticos, são utilizados pelos jovens, a exemplo do Museu de Arte Contemporânea (MAC) e o Centro Universitário de Cultura e Arte (CUCA), ambos vinculados à UEFS e que são disponibilizados para reuniões dos grupos que pautam, por exemplo, a realização de eventos (grafitagens, exposições, lançamentos de livros, vídeos, etc.) e ensaios, ou ainda debates políticos de natureza contestatória ou reivindicatória em torno dos direitos sociais (equipamentos de lazer, segurança, acesso à universidade e aos bens culturais).

ARTE ENGAJADA:

"QUE PALAVRA SERÁ PROIBIDA SE QUERO TE DESENHAR?"

O cenário cultural independente em Feira de Santana integra eventos onde a produção e o consumo cultural aliam-se também à sociabilidade e ao protagonismo juvenil. Conectados a circuitos onde se pratica um modelo autônomo e descentralizado de organização de eventos e intervenções artísticas, nos deparamos com o coletivo literário DiaboA4, que promove recitais de poesia e lançamentos de livros e do qual Larissa Rodrigues faz parte: "Na verdade, 
a gente coleta textos de pessoas que estejam interessadas em produzir poesia, especialmente a partir de determinada temática e, a partir dessa temática, a gente faz o lançamento do livro".

Chegamos a Larissa, primeiramente, quando convocamos o DiaboA4 a participar dos nossos grupos de diálogo. Na ocasião, notamos sua eloquência e entusiasmado engajamento com o cenário artístico e cultural independente da cidade. Posteriormente, a convidamos para participar de uma entrevista mais detida. Encontramos Larissa no Museu de Arte Contemporânea, espaço escolhido por ela, por sua forte relação com o lugar, que abriga exposições e no qual o DiaboA4 realiza eventos, apoiando artistas novos e independentes da cidade.
"Sou preta
Pobre
Poeta
E professora
Conheço quase tudo sobre a coragem"

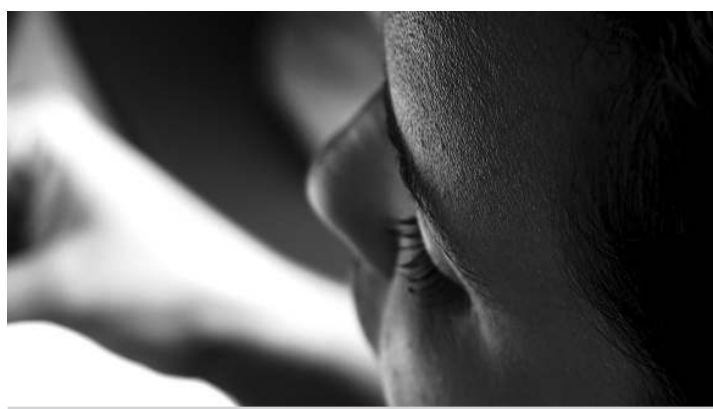

Figura 5 - Larissa Rodrigues, poeta.

É desta maneira que Larissa Rodrigues, 28 anos, parafraseando Sergio Vaz, poeta paulistano, define-se: "vastamente" como mulher, negra e professora.

Ainda antes de falar sobre sua atuação no coletivo literário, Larissa nos conta do começo da sua inquietação poética enquanto estudante do curso de Letras da Universidade Estadual de Feira de Santana e da necessidade da escrita como um posicionar-se fora de si, "do eu se posicionar [...] como necessidade de sobrevivência".

Larissa revela a necessidade de interagir com a cidade através de sua escrita poética e, mais radicalmente, pelo ativismo cultural, sobretudo na formação de plateia, ampliando as possibilidades estéticas para além do que as pessoas vivenciam cotidianamente.

Ademais do sentido estético, Larissa acredita que sua atuação tem um alcance político, desde quando a arte oferece acesso a uma reflexividade que desloque o sujeito da posição de espectador passivo. Isto se dá quando "o poema causa riso, causa uma discussão".

Quanto ao papel da arte e da mobilização cultural, para ela é "Papel de formação, de acesso à informação política, cultural e estética, e isso intrinsecamente ligado, mas eu só vou poder fazer isso se eu tiver acesso a outras formas de pensamento". 
Da dimensão pessoal e subjetiva da arte, emerge a dimensão coletiva e política da ação cultural e da produção em rede, através da integração de linguagens e de artistas independentes. Daí para o ativismo cultural, contou com o impulso dos amigos escritores e das brechas que foram preenchendo na vida cultural da cidade. Ressonâncias que, segundo Larissa, potencializam uma formação do olhar do espectador para novas sensibilidades.

Sua estreia se deu em 2012 junto ao DiaboA4, com o lançamento de uma antologia de poesia erótica. Em seguida houve uma segunda publicação, em forma similar, cuja inquietação-tema foi a "cidade", lançada em 2013, no Museu de Arte Contemporânea, durante um evento multiartístico que reunia poesia, vídeo, dança e música, suprindo, segundo Larissa, uma lacuna de festivais dessa natureza na cidade.

A relação forte que a jovem tem com Feira de Santana, sua cidade de origem e onde pretende seguir sua trajetória, transmuta-se em verso:

"Que palavra será proibida se quero te desenhar?

Ruas, praças, avenidas

Se sou espelho a te olhar

E de teu pôr do sol sangrento

Sons sobre tuas horas

Feroz teu firmamento

E ardorosas auroras

Que 'nãos' me terão a dizer?

Se tudo se colhe em teu seio

E se tua esquina é sempre entremeio

Quem sou no banquete da realeza?

Paus, pedras, bichos e gente

Província e cinzas de tua dureza"

["Roda", Larissa Rodrigues].

Larissa projeta um momento de maior abertura e consolidação de projetos culturais com a emergência de políticas públicas e da atuação no Conselho de Cultura de Feira de Santana, da qual faz parte como suplente na cadeira de Literatura.

As expressões culturais e, neste caso, especificamente, pela literatura produzem um espaço simbólico, cuja dimensão estética projeta-se numa dimensão política pela sua porosidade. Neste ponto, a ideia de resistência cultural desenvolvida por Duncombe (2002) sinaliza para a importância de compreendermos as formas como grupos, coletivos e indivíduos dinamicamente buscam transformar o sistema cultural (comportamentos, normas, linguagens, bens) e as estruturas sociais, políticas e econômicas dominantes, ao desenvolverem recursos e estratégias de resistência, mais ou menos conscientes. 
Inspirando-nos em Tommasi (2013: 19) ao fazer referência aos "artistas periféricos”, indagamos, por outro lado, sobre os limites políticos enfrentados pelos jovens agentes culturais, uma vez que tornam-se "produtores de si mesmos: produzem livros, organizam saraus e outros eventos para difundir suas obras". Organizam-se como poderes oblíquos, por baixo ou pelas bordas, mobilizando outros artistas e outros públicos, para difundir a cultura, como resistência, em espaços alternativos.

O K-POP E A (RE)CONSTRUÇÃO DE IDENTIDADES

E SUBJETIVIDADES JUVENIS

O Kiken-sei é um grupo de jovens de Feira de Santana, reunidos em torno de seu interesse pela dança e que se dedica a fazer covers de coreografias de artistas e grupos de K-pop. Reúnem-se semanalmente para realizar seus ensaios. Nos vídeos que disponibilizam em seu canal no YouTube, percebemos a dedicação que têm à dança, o apuro cênico de suas coreografias e o cuidado com os figurinos que utilizam. Além disso, os vídeos e os comentários feitos por seus seguidores indicavam a existência de um circuito de eventos dos quais participam com certa regularidade.

Ainda em 2013, cinco pessoas compunham o grupo: Tonny (21 anos), Sabrina (19), Natty (16) e as irmãs Adrielly e Anny (15). Com exceção de Tonny e Sabrina, as demais integrantes estavam ainda na escola de educação

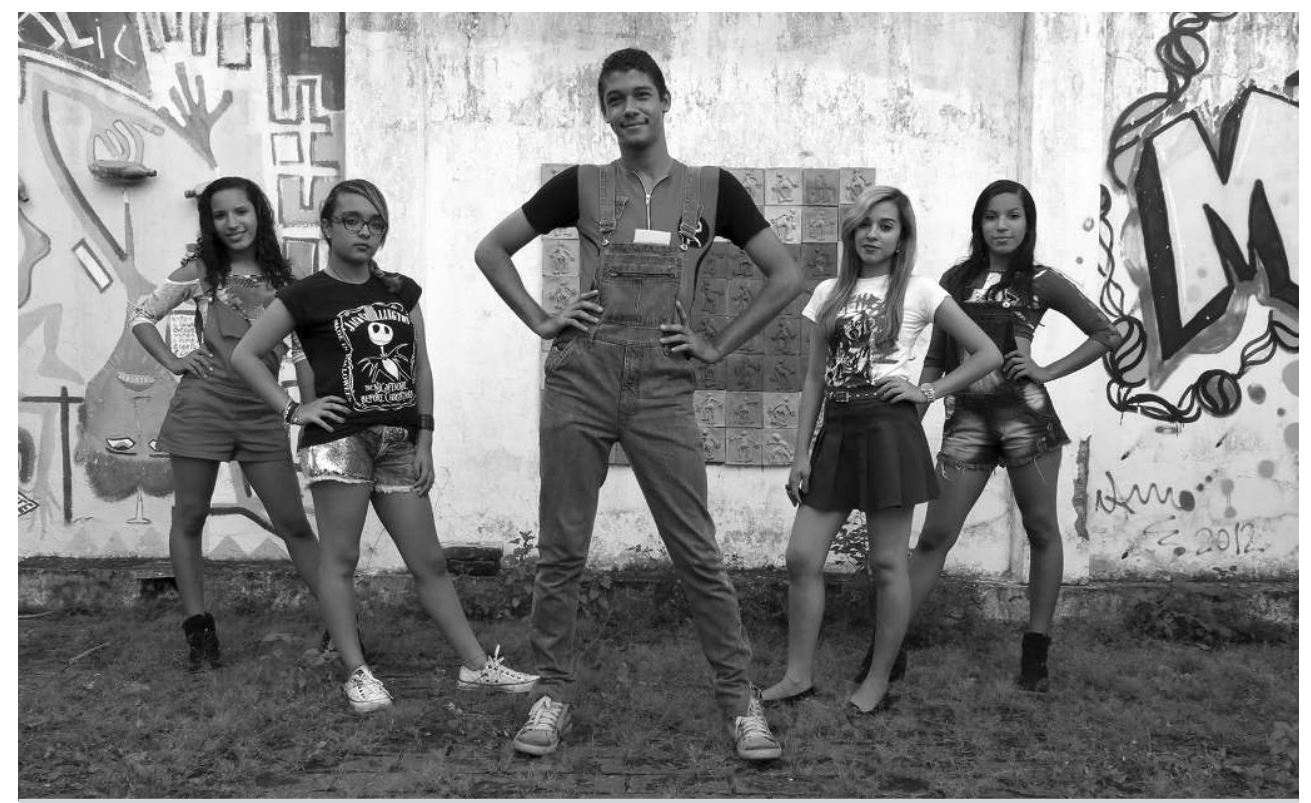

Figura 6 - Kiken-Sei. 
básica. Sabrina é estudante do curso de letras da Universidade Estadual de Feira de Santana e Tonny havia, então, recém-ingressado no curso de Filosofia, na mesma instituição. De todo o grupo, Tonny e Sabrina eram os mais falantes, demonstrando, desde o início, entusiasmo e interesse nos contatos que passamos a travar, tanto pela Internet quanto pessoalmente. Sabrina esteve com Tonny desde antes da criação do grupo, unidos pela amizade e pelos interesses musicais e estéticos comuns, além de ambos morarem no mesmo bairro (Feira VII), bem nas imediações da escola municipal que thes cede uma sala para seus ensaios.

Em maio de 2014, acompanhamos uma apresentação do grupo numa edição do Anihime, um evento local que reúne exposições, gamers, cosplay, RPG, pop nipônico e bandas de rock - todas as tribos que se encontram ligadas ao universo da chamada "cultura alternativa" de Feira de Santana.

Num e-mail enviado para o nosso grupo de pesquisa, um de nossos pesquisadores/observadores assim se manifestou acerca daquilo que viu deles:

“O Kiken-sei é muito bacana. São performátic@s e é tão natural que sejam assim.

Eles parecem não ligar para mais nada que não seja dançar. E são ótimos de fotografar: fazem pose em qualquer situação, sem se importar com mais nada para além ou aquém da alegria deles. Dançam e se divertem, suam à pampa quando estão fazendo seus números de dança, mas não é do esforço

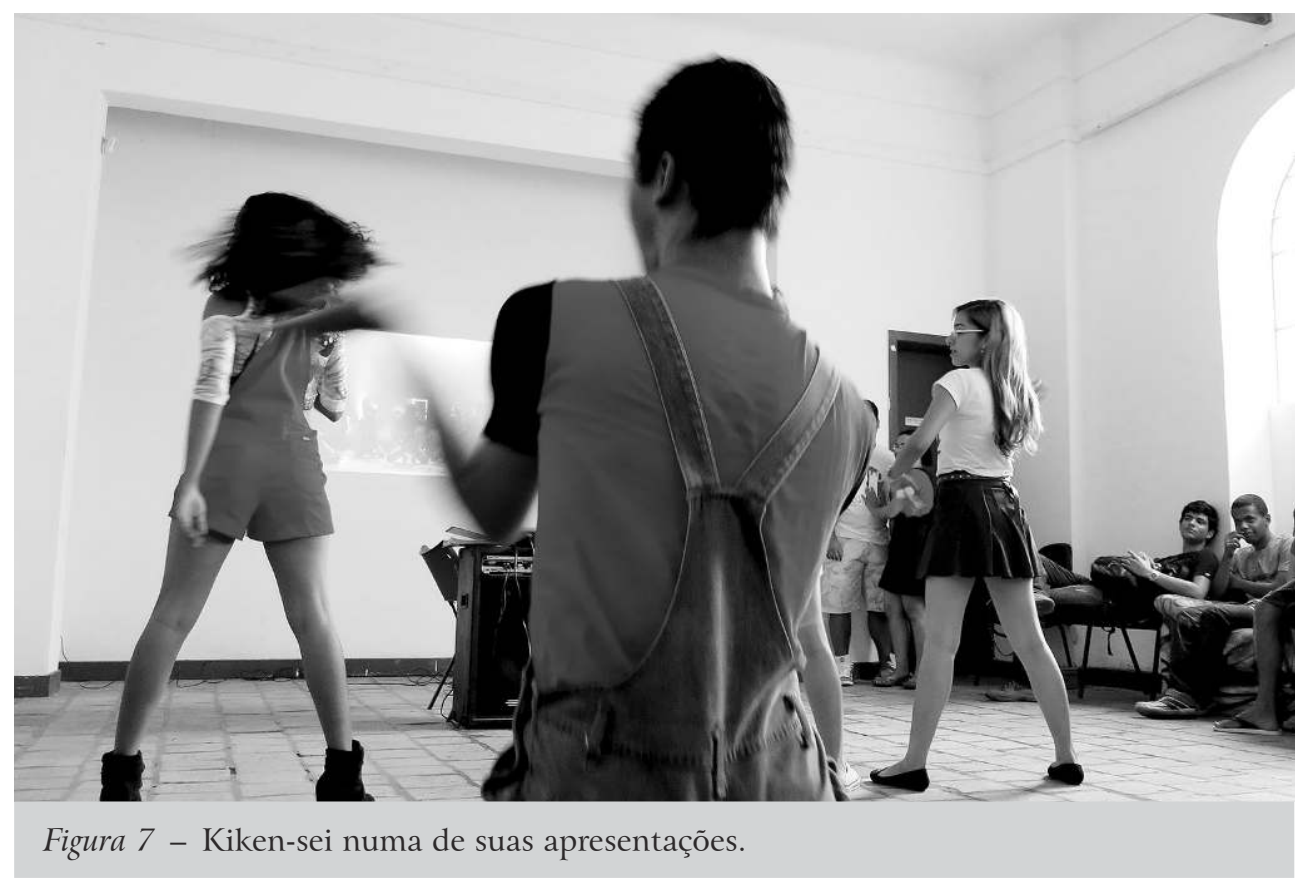


que fazem (nada parece forçado neles), e sim porque se sentem contagiados (e contagiantes eles são) pela música e pela alegria.

Para além das questões comuns ao nosso grupo de pesquisa - juventude e inserção social, os mecanismos de sociabilidade promovidos, facilitados, criados, por intermédio desse envolvimento intenso com (e por causa da) arte e da cultura, e por intermédio dos coletivos culturais da cidade - há algo que me atrai muito neles: a corporeidade, a alegria do movimento e da dança, as questões que envolvem gênero e sexualidade (e esta encarada com tanta naturalidade, não só pelos membros do grupo, mas pelas pessoas que acompanham ou assistem as apresentações do grupo).

As demarcações típicas, conservadoras e tradicionais, de gênero/sexualidade parecem dissolvidas sem esforço e sem conflito no momento em que elas e ele dançam; a plateia parece não estar nem aí para o fato de que há um rapaz dançando de forma tão graciosa e descontraída”.

Em nossos encontros, pudemos perceber o Kiken-sei como um grupo de jovens que encontrou, na dança e na cultura de mídia contemporânea (algo que envolve consumo, estilo, lazer, sociabilidade e corporeidade), tanto um meio de expressão de seus afetos e anseios juvenis, como também um espaço lúdico e simbólico através do qual afirmam identidades e posições de sujeito, o que, de outro modo, talvez não lhes fosse possível.

O entusiasmo pela dança e pelo K-pop situa-os no interior de certas práticas de sociabilidade, as quais parecem se tornar possíveis por intermédio de uma cultura juvenil contemporânea e cosmopolita, originada, demarcada e atravessada pelos meios massivos de comunicação e informação. $\mathrm{O}$ forte apelo audiovisual, potencializado pela facilidade com que as informações são geradas e disseminadas pela Internet, ajuda a criar e a reforçar laços de pertencimento grupal. Tais práticas de sociabilidade parecem demarcar espaços lúdicos de negociação e resistência relativamente aos papéis de gênero e sexualidade entre estes jovens.

À primeira vista, o K-pop e a dança do Kiken-sei nos pareciam um mero entretenimento juvenil, além de muito pouco original - afinal, o grupo se empenha em fazer covers, ou seja, imitações de coreografias já existentes. Neste sentido, que relevância cultural e artística teria um gênero como o K-pop? Não seria apenas mais uma moda passageira, importada e moldada pelos padrões da cultura pop estadunidense?

No entanto, sem os aspectos disruptivos e contestatórios que marcaram os movimentos de contracultura juvenis das décadas de 60 e 70, e ainda que não pareça haver nenhum grande dissenso para com aquilo que estrutura suas vidas cotidianas, não poderíamos deixar de perceber a intensidade do envolvimento destes jovens com a música, com a dança e com o estilo que os anima e que parece lhes fornecer os significados e os sentidos que ajudam fortemente a constituir suas interações sociais e suas subjetividades. 
“- O K-pop está na vida de vocês desde quando?

De repente, todos começam a falar ao mesmo tempo e a fazer contas, 'pra mim, veio em 2009, 2010...' Alguém diz 'ah, tenho de contar porque eu sempre esqueço’. Alguém estabelece como marco importante o lançamento de um vídeo: 'foi quando lançou aquele vídeo de Big Bang...'; 'O meu primeiro vídeo foi o do Girl Generation...'; 'foi, foi', todos falam animadamente sobre os vídeos que viram e que os inspiraram. Uma profusão de nomes de grupos e bandas são enunciados alegremente: Girl Generation, 2PM, Four Minute...

Sabrina: aquele [vídeo] que elas estão correndo assim, na piscina, que elas estão vestidas de salva-vidas.

Tonny: ... aquele é com o 2PM.

Outras vozes confirmam, 'ah, eu sei qual é'.

Sabrina: Aquele foi o meu primeiro [vídeo].

Tonny: Eu achava que o meu primeiro foi 'Hot Issue', porque a gente dançava 'Hot Issue', mas, mentira, meu primeiro foi o vídeo que Cindy tava chamando as meninas pra dançar, que foi, ó, do Girl Generation, que hoje eu acho insuportável!

Sabrina: Ah! Aquele da calça colorida?

Tonny: ... o das botas rosas [...] eu ficava tonto, eu assistia o vídeo delas e, meu Deus!, todas iguais!, me dava agonia aquilo ali! Mas hoje em dia adoro Girl Generation".

A cultura de mídia contemporânea, para além dos criticismos que lhe atribuem os piores defeitos do capitalismo - a padronização, o consumismo, o esvaziamento individualista dos ideais de transformação social -, pode vir a ser também a principal e talvez a única forma pela qual os jovens podem fruir e vivenciar arte, bem como participar de comunidades de afeto que transcendem e superam barreiras geográficas e culturais. Neste sentido, concordamos com Appadurai, quando nos diz que

“... é errado presumir que a comunicação eletrônica é o ópio do povo. Esta posição, que apenas começa a ser corrigida, baseia-se na noção de que os processos mecânicos de reprodução reprimem severamente a gente comum que busca trabalho industrial. [...] Cada vez mais há provas de que o consumo de comunicação de massas origina em todo o mundo resistência, ironia, seletividade e, em geral, impulso para a ação" (Appadurai 1996: 19).

Assim, tomamos como inspiração o trabalho de Bispo (2009: 19) sobre a juventude emo do Rio de Janeiro, para apontar para outras possibilidades contestatórias e desafiadoras, nas quais dissensões e conflitos da vida cotidiana 
são instigados, "mesmo que suas provocações tenham dimensões microssociológicas e nem um pouco 'monumentais'".

É aqui que a corporeidade - uma forma particular de afirmar o corpo como uma presença distinta e importante - assume proeminência. Se quisermos compreender o que mobiliza tão intensamente estes jovens, devemos ter como pista este apelo particular ao corpo e, consequentemente, suas implicações sociais face àquilo que se tem como adequado ou não em termos dos papéis hegemônicos de gênero e sexualidade.

“- Como é que os familiares de vocês e os amigos de vocês veem esse envolvimento com a dança?

Natielle: Meus amigos, eles gostam muito. Agora, tem uns assim que têm um certo preconceito por ser K-pop, né?

- Por que?

Natielle: Porque, K-pop, assim, por ser da cultura asiática e parecer ser um pouco 'fofo', assim... geralmente, os meninos...

- Fofo?

Natielle: É, na maioria das vezes, é fofo, aí os meninos ficam com essa coisa, 'ah, que negócio gay'...

$[\ldots]$

Natielle: No Kiken-sei, acho que a pessoa que mais sofre preconceito é Tonny. [As demais garotas confirmam.] Porque Tonny, por ser do sexo masculino, as pessoas enxergam isso como...

- Como algo que não seria apropriado para rapazes?

Natielle: É, todo mundo sabe que o preconceito aqui é contra a sexualidade da pessoa, né? O Kiken-sei tende a fazer covers mais dos grupos femininos, aí as pessoas ficam mais... com preconceito pro lado dele.

- Mas vocês enfrentam preconceito?

Tonny: Eu nunca cheguei a... [hesita um pouco] a sentir muito forte, diretamente, sabe? Até porque nosso público tá lá no meio daquilo, já sabe como é".

Uma política identitária é levada a cabo quando ele e elas dançam. E apesar de o K-pop não ser, a priori, um gênero que se defina a partir de certas identidades ligadas à sexualidade (ou à contestação dos papéis sexuais hegemônicos), ele cria, pelo menos para o Kiken-sei, um espaço simbólico no qual parece ser permitido vivenciar o corpo sem as amarras dos padrões heteronormativos e dos preconceitos de gênero e sexualidade.

Se, como nos diz Hall (2004), as identidades emergem e se definem a partir de diálogos e negociações que se dão no interior de representações culturais, devemos pensar nossas subjetividades como algo que se institui discursiva e dialogicamente através do jogo e da política das representações. É neste sentido 
que a dimensão política da corporeidade, no Kiken-sei, não deve ser ignorada ou subestimada.

Enfim, há uma política do corpo que se estabelece junto à formação de certas sensibilidades e de certos sentidos que muito provavelmente não poderiam se dar senão por intermédio destas formas renovadas de se viver a arte e a cultura. A cultura de mídia, mundializada, cosmopolita, que se dissemina e "viraliza" através da Internet e de suas redes sociais - textos, imagens, música concorre fortemente para a construção das subjetividades juvenis.

\section{CONSIDERAÇÕES FINAIS}

Percebemos que os circuitos culturais construídos pelos jovens via redes de sociabilidade não seguem uma forma de organização sistemática, mas trazem características de "permanências" e "regularidades", expressas em suas práticas artísticas (Magnani 2005) e são fruto do desejo e da ação espontânea de grupos e de lideranças, sobretudo apostando nas relações de parceria e amizade, que são fundamentais para que projetos culturais aconteçam na periferia, por exemplo.

Vimos como as redes de sociabilidade se tramam em espaços não convencionais, ocupam espaços públicos, nas ruas, nas praças ou subvertem espaços convencionais como a escola, ampliando as experiências estéticas e a emergência de novas sensibilidades na formação de plateia e no encontro com o outro, quando a arte convoca o espectador como autor/ator (Magnani 2005; García Canclini, Cruces e Urteaga 2012).

Se podemos sinalizar algumas similaridades nos sentidos atribuídos pelos jovens às suas práticas culturais, como as sociabilidades, trocas e afetos que os movem e na sua relação com o público, é bom destacar as diferenças, sem hierarquizá-las em escalas valorativas. Enquanto os artistas e divulgadores da cultura K-pop na cidade de Feira de Santana têm como "filosofia" o culto do prazer e da alegria por meio da dança, notamos no grafite e no hip-hop a ênfase em um discurso contestatório dirigido à transformação de um quadro social excludente econômica e culturalmente. Em perspectiva não exatamente oposta, encontra-se o circuito dos artistas independentes, que igualmente ocupa espaços distintos da cidade com a poesia lírica ou erótica, ampliando esse mosaico das linguagens artísticas, colorindo o solo árido da cidade, preenchendo quiçá timidamente lacunas culturais.

As relações de troca e a educação via arte são pontes importantes - a exemplo, o circuito do hip-hop, quando revela conexões artísticas e rotas comuns entre Leo, Kbça e Coelho, tanto no trabalho dentro da comunidade, como no trabalho social em instituições de abrigamento.

Outra característica vinculada aos artistas independentes é que eles viabilizam o acesso e a circulação de um público diverso em espaços democráticos, 
reunindo pessoas com diferentes gostos e estilos. Tais formas de apropriação e recriação da cultura são elementos contemporâneos importantes para pensarmos na mobilidade, circularidade e porosidade das fronteiras urbanas e no direito à cidade.

A importância das mídias digitais na configuração de redes e formas de sociabilidade novas também é elemento contemporâneo fundamental para pensarmos nas formas de circulação dos bens culturais, criando comunidades mundializadas via Internet (García Canclini, Cruces e Urteaga 2012; Bennet e Robards 2012). Como observamos, as redes sociais constituem canais de diálogo e reflexão que potencializam a participação criativa dos seus membros e ampliam formas de pertencimento e empoderamento que extrapolam territórios.

A pesquisa valeu-se de alguns dispositivos teórico-metodológicos influenciados pelo método cartográfico e que potencializaram a sua dimensão ética e política, vale dizer, comprometidos com a visibilidade de atores sociais que produzem arte e novas discursividades. Como produção criativa das margens, desvelou as tramas que os jovens constroem em circuitos autônomos e menos prescritivos e buscou potencializar redes colaborativas emergentes. Colocamo-nos como parte desta rede que pensa a cidade em suas fronteiras e porosidades, fortalecendo as ações e eventos organizados pelos grupos. Consideramos, por outro lado, os limites políticos da dimensão contestatória por meio da arte num contexto de vulnerabilidades, expressão das extremas desigualdades sociais e falta de políticas públicas. O direito pleno à cidade nos espaços periféricos se apresenta, assim, longínquo (Tommasi 2013).

Abrir processos de diálogo com os jovens e produzir imagens em movimento sobre a cidade foram dispositivos criativos e dinâmicos significativos para uma pesquisa que pretende fortalecer redes comunicativas e colaborativas e dar visibilidade a processos criativos que visam transformação social. 


\section{BIBLIOGRAFIA}

APPADURAI, Arjun, 1996, Dimensões Culturais da Globalização: A Modernidade sem Peias. Lisboa, Teorema.

ARANTES, Otilia, 2000, "Uma estratégia fatal: a cultura nas novas gestões urbanas", em O. Arantes, C. Vainer e E. Maricato (orgs.), A Cidade do Pensamento Único: Desmanchando Consensos. Petrópolis, Vozes, 1 1-74.

BENNET, Andy, 2011 , “The post-subcultural turn: some reflections 10 years on”, Journal of Youth Studies, 14 (5): 493-506.

BENNET, Andy, e Brady ROBARDS, 2012, "Editorial: continuum", Journal of Media \& Cultural Studies, 26 (3): 339-341.

BISPO, Raphael, 2009, Jovens Werthers: Antropologia dos Amores e Sensibilidades no Mundo Emo. Rio de Janeiro, UFRJ/Museu Nacional/Programa de Pós-Graduação em Antropologia Social, dissertação de mestrado.

CAMPOS, Ricardo, 2009, "Entre as luzes e as sombras da cidade: visibilidade e invisibilidade no graffiti”, Etnográfica, 13 (1): 145-170.

CHO, Glorya, 2010, "Hiplife, cultural agency and youth counter-public in the Ghanaian public sphere", Journal of Asian and African Studies, 45 (4): 406-423.

CLARKE, John, et al., 2006, "Subcultures, cultures and class", em S. Hall e T. Jefferson (orgs.), Resistance through Rituals: Youth Subcultures in Post-War Britain. Londres e Nova Iorque, Routledge, 3-59.

DAS, Veena, e Deborah POOLE, 2009, "State and its margins: comparative ethnographies", em V. Das e D. Poole (orgs.), Anthropology in the Margins of the State. Santa Fé, School of American Research, 3-34.

DEDMAN, Todd, 2011, "Agency in UK hip-hop and grime youth subcultures: peripherals and purists", Journal of Youth Studies, 14 (5): 507-522.

DUNCOMBE, Stephen, 2002, Cultural Resistance Reader. Londres e Nova Iorque, Verso, 182$-192$.

GARCÍA CANCLINI, Néstor, 1997, “Culturas híbridas, poderes oblíquos”, em N. García Canclini, Culturas Híbridas: Estratégias para Entrar e Sair da Modernidade. São Paulo, Edusp, 283-350.

GARCÍA CANCLINI, Néstor, Francisco CRUCES, e Maritza URTEAGA (orgs.), 2012, “Jóvenes, cultura urbana y redes digitales: prácticas emergentes em las artes, las editoriales y la música", Madrid, Fundación Telefonica; Barcelona, Editorial Ariel, disponível em $<$ https://www.fundaciontelefonica.com/arte_cultura/publicaciones-listado/pagina-item -publicaciones/itempubli/164/ > (última consulta em junho de 2018).

HALL, Stuart, 2004, A Identidade Cultural na Pós-Modernidade. Rio de Janeiro, DP\&A (9. ${ }^{\text {e edi- }}$ ção).

HALL, Stuart, e Tony JEFFERSON (orgs.), 2006, Resistance through Rituals: Youth Subcultures in Post-War Britain. Londres e Nova Iorque, Routledge.

JOHANSSON, Thomas, e Phillipe LALANDER, 2012, "Doing resistance: youth and changing theories of resistance", Journal of Youth Studies, 15 (8): 1078-1088.

JOVCHELOVITCH, Sandra, e Jaqueline PRIEGO-HERNANDEZ, 2013, Sociabilidades Subterrâneas: Identidade, Cultura e Resistência nas Favelas do Rio de Janeiro. Brasília, UNESCO.

KASTRUP, Virgínia, 2010, "O método da cartografia e os quatro níveis da pesquisa-intervenção”, em Eduardo Passos, Virgínia Kastrup e Liliana da Escóssia (orgs.), Pistas do 
Método da Cartografia: Pesquisa-Intervenção e Produção de Subjetividade. Porto Alegre, Editora Sulina, 32-51.

MAGNANI, José Guilherme C., 2005, "Os circuitos dos jovens urbanos”, Tempo Social: Revista de Sociologia da USP, 17 (2): 173-205.

MILLER, Toby, 2011, "Cidadania cultural”, Matrizes, 2 (4): 57-74.

PAIS, José Machado, 2005, "Jovens e cidadania”, Sociologia, Problemas e Práticas, 49: 53-70.

PAIS, José Machado, 2006, Nos Rastos da Solidão: Deambulações Sociológicas. Porto, Âmbar.

RAPOSO, Otávio, 2012, “Coreografias de evasão: segregação e sociabilidade entre os jovens do break dance das favelas da Maré”, Etnográfica, 16 (2): 315-338.

ROCHA, Ana Luiza Carvalho da, e Cornelia ECKERT, 2003, "Etnografia de rua: estudo de antropologia urbana", Rua, 9: 101-127, disponível em < https://periodicos.sbu.unicamp. br/ojs/index.php/rua/article/view/8640752 > (última consulta em junho de 2018).

TOMMASI, Lívia de, 2013, "Culturas de periferia: entre o mercado, os dispositivos de gestão e o agir político", Política e Sociedade, 12 (23): 12-34. 